\title{
On the genus Psalistopoides Mello-Leitão (Araneae, Mygalomorphae, Nemesiidae)
}

\author{
Sylvia M. Lucas \& Rafael P. Indicatti
}

Laboratório de Artrópodes, Instituto Butantan. Avenida Vital Brazil 1500, 05503-900 São Paulo, São Paulo, Brasil. E-mail: sylvialucas@butantan.gov.br; indicatti@butantan.gov.br

\begin{abstract}
The genus Psalistopoides Mello-Leitão, 1934, previously a junior synonym of Pselligmus Simon, 1892, is revalidated. Psalistopoides fulvimanus Mello-Leitão, 1934 is redescribed and new distribution records are presented. In addition, P. emanueli sp. nov. is described from the State of Paraná, Brazil. KEY WORDS. Atlantic Forest; Psalistopoides emanueli sp. nov.; Psalistopoides fulvimanus; Pycnothelinae.
\end{abstract}

RESUMO. Sobre o gênero Psalistopoides Mello-Leitão (Araneae, Mygalomorphae, Nemesiidae). O gênero Psalistopoides Mello-Leitão, 1934, considerado anteriormente sinônimo junior de Pselligmus Simon, 1892, é revalidado. Psalistopoides fulvimanus Mello-Leitão, 1934 é redescrita e novos registros de sua distribuição são apresentados. Psalistopoides emanueli sp. nov. é descrita para o Estado do Paraná, Brasil.

PALAVRAS-CHAVE. Mata Atlântica; Psalistopoides emanueli sp. nov.; Psalistopoides fulvimanus; Pycnothelinae.

The genus Psalistopoides was proposed by Mello Leitão (1934) to include $P$. fulvimanus Mello-Leitão, 1934, described from Alto da Serra de Paranapiacaba, Santo André, São Paulo, Brazil, based on a single male specimen. The species was synonymized with Neostothis gigas Vellard, 1924 by BücherL et al. (1971), and thus Psalistopoides was placed as a junior synonym of Neostothis Vellard, 1924. Two years later, after studying the type material deposited in the Collection of the Instituto Butantan, São Paulo. LuCAS \& BüCHERL (1973) confirmed the validity of $P$. fulvimanus and, based on the absence of claw tufts and labiosternal suture, and the presence of four spinnerets and scopulae on all tarsi, transferred the revalidated Psalistopoides from Barychelidae to Pycnothelidae.

Raven (1985) synonymized Psalistopoides with Pselligmus Simon, 1892 based on the absence of a third claw on tarsi I-III and the weak scopulae on the legs. However, Goloboff (1995) suggested that Pselligmus is represented solely by $P$. infaustus Simon, 1892 and that Psalistopoides could either be a valid genus or a junior synonym of Stenoterommata Holmberg, 1888. Goloboffs' suggested that Psalistopoides "lacks tibial scopulae and has a longer apical article of the posterior lateral spinerets".

After studying the type specimen of Psalistopoides fulvimanus and specimens deposited in the collections of the Instituto Butantan, São Paulo, and Secretaria de Saúde do Estado do Paraná, Curitiba, we consider that Psalistopoides is a valid genus and thus present additional information on its description and enhance the geographical distribution. In addition, we describe a new species from Ribeirão do Pinhal, Paraná, Brazil, increasing to two the number of species of the genus.

\section{MATERIAL AND METHODS}

The material examined is deposited in the following institutions (abbreviation and curator in parenthesis): Instituto Butantan, São Paulo (IBSP, A.D. Brescovit) and Centro de Produção e Pesquisa de Imunobiológicos, Secretaria de Estado da Saúde do Paraná, Curitiba (CPPI, E. Marques da Silva). Spine notation follows IndicatTI \& LuCAS (2005). All measurements are in millimeters. Abbreviations: (AME) anterior median eyes, (ALE) anterior lateral eyes, (PLE) posterior lateral eyes, and (PME) posterior median eyes.

\section{Psalistopoides Mello-Leitão, 1934 Figs 1-3}

Psalistopoides Mello-Leitão, 1934: 403, figs 3-4, type-species by original designation and monotypy, Psalistopoides fulvimanus Mello-Leitão, 1934; Petrunkevitch, 1939: 300; Roewer, 1942: 222; Bonnet, 1958: 3797; Bücherl et al., 1971: 127 (synonimized with Neostothis Vellard, 1924); Lucas \& Bücherl, 1973: 240, fig. 2 (revalid).

Pselligmus Simon, 1892: 273; Raven, 1985: 107, figs 148-156 (syn.); Goloboff, 1995: 30; Platnick, 2006.

Diagnosis. Species of the genus Psalistopoides differ from those of the other genera of Pycnothelinae by the following characteristics: from Neostothis and Prorachias Mello Leitão, 1924 by the presence of keels close to the embolus; from Pselligmus by the presence of tarsal scopulae on legs III and IV; from Stenoterommata Holmberg, 1888 by the absence of a megaspine on tibia I and the aspect of the palpal bulb; from Rachias Simon, 1892 , by the absence of spines on all tarsi on posterior legs and 
from Pycnothele Chamberlin, 1917 by the longer embolus.

\section{Psalistopoides fulvimanus Mello-Leitão, 1934}

\section{Figs 1-3}

Psalistopoides fulvimanus Mello-Leitão, 1934: 404, figs 3-4, (male holotype from Alto da Serra de Paranapiacaba, Santo André, São Paulo, Brasil, deposited in IBSP 3428, examined (previously number 18); Petrunkevitch, 1939: 300; Roewer, 1942: 222; Bonnet, 1958: 3797; Bücherl et al., 1971: 127 (synonimized with Neostothis gigas Vellard, 1924); Lucas \& Bücherl, 1973: 240, fig 2 (revalid).

Pselligmus fulvimanus, Raven 1985: 107, figs 148-156 (new combination); Goloboff 1995: 30; Platnick 2006.

Diagnosis. The males of Psalistopoides fulvimanus differ from those of $P$. emanueli sp. nov. by the apical area of the embolus, wider and more curved (Figs 1 and 2).

Description. Male (holotype). Coloration pattern: carapace and legs brown. Abdomen brown. Total length, excluding chelicerae, 21.00. Carapace 11.00 long, 10.00 wide, with fovea short and procurved. Clypeus present, narrow, 3.75. Overall shape of eye group trapezoidal, wider than long in ratio. Anterior eye row procurved, posterior slightly recurved. AME as large as ALE, ALE larger than PLE and PME smaller than PLE. Basal segment of chelicerae with nine teeth in a row and rastellum with very strong setae. Intercheliceral tumescence large and pale, covered by few hairs. Labium 1.10 long, 2.00 wide, with two cuspules. Each endite with 45 cuspules. Sternum 5.30 long, 4.70 wide. Posterior sternal sigilla median and submarginal. Palp, measurements: femur 5.36/ patella 2.80/ tibia 4.00/ cymbium 2.05/ total 14.21 ; spination: femur d0-0-2, patella p1, tibia d0-0-2, v0-0-1, p0-2-3, cymbium 0. Legs: measurements: I: femur $10.48 /$ patella $4.96 /$ tibia 7.36/ metatarsus 9.36/ tarsus 5.76/ total 37.92; II: 9.68/5.08/ 7.28/9.28/5.76/37.08; III: 8.80/4.56/6.32/10.32/5.76/35.76; IV: 9.68/5.12/8.96/12.24/6.56/42.56; spination: I: femur d1-3-5, patella 1 , tibia v2-4-0 (3ap), r0-1-1, megaspine absent, metatarsus r0-1-0, v2-2-1 (3ap), p0-1-0; II: femur d2-3-4, patella p2, tibia v23-0 (3ap), p0-1-0, metatarsus d0-1-0, r0-1-0, v2-2-1 (3ap); III: femur d0-5-2, patella d1, p2, tibia d3-3-3, v2-3-0 (3ap), r0-1-0, p10-1, metatarsus d3-2-2, v2-1-2 (3ap), p0-1-1; IV: femur d1-2-5, patella r1, tibia d1-0-1, r0-1-1, v2-3-1 (3ap), p0-1-0, metatarsus d2-6-3, v1-2-4 (3ap), p0-1-0, r0-1-1. Scopulae of tarsi II, III, IV divided by a row of thin setae. Third claw present on tarsus IV. Superior tarsal claws large with a double row of six to eight teeth each. Four spinnerets. Apical segment of the posterior lateral spinnerets short, triangular. Palp with elongate tibia. Embolus distally twisted at $180^{\circ}$ with conspicuous opening at tip (Fig. 2).

Female. Unknown.

Variation. Coloration pattern of the abdomen can be dark brown with no stains or dark brown with randomly distributed stains. Total length 21.00-22.80. Labium with 2-5 cuspules and endites with 45-50.

Distribution. South and Southeastern Brazil, states of São Paulo and Paraná.

Revista Brasileira de Zoologia 23 (2): 547-549, junho 2006
Other material examined. BrAzIL, São Paulo: Santo André (Alto da Serra de Paranapiacaba), 1 male, 1933 (IBSP 12352), 4 males, (IBSP 3716), Primavera (Usina Hidrelétrica Engenheiro Sérgio Motta), 1 male, XII.1998, I. Knysak \& R. Martins leg. (IBSP 10510). Paraná: Jacarézinho, 1 male, 24.X.1997 (CPPI 1031); 1 male, 03.XI.1997 (IBSP 10953); 1 male, XII.1997, M.E. Souza leg. (CPPI 1041), Curiúva (Fazenda Figueira), 1 male, V.1973 (IBSP 2168B).

\section{Psalistopoides emanueli sp. nov.} Figs 4-6

Types. Male holotype from BraziL, Paraná: Ribeirão do Pinhal, 19.X.2004, J. Baherra leg., deposited in IBSP 10994. Male paratype with the same data as holotype (CPPI 1501).

Etymology. The specific name patronym in honour of Emanuel Marques da Silva, curator of the collection of the Centro de Produção e Pesquisa de Imunobiológicos, Secretaria de Estado da Saúde do Paraná, Coleção Aracnológica Vera Regina von Eickstedt, Curitiba.

Diagnosis. The males of Psalistopoides emanueli sp. nov. differ from those of $P$. fulvimanus by the apical area of the embolus, thinner and less dilatated at tip (Figs 4-6).

Description. Male (holotype). Coloration pattern: carapace and legs dark brown. Abdomen brown with randomly distributed stains. Total length, excluding chelicerae, 18.30. Carapace 9.60 long, 7.90 wide, with fovea short and procurved. Clypeus present, narrow, 2.50. Overall shape of eye group trapezoidal, wider than long in ratio. Anterior eye row procurved, posterior slightly recurved. AME smaller than ALE, ALE larger than PLE and PME larger than PLE. Basal segment of chelicerae with eight teeth in a row and rastellum with very strong setae. Intercheliceral tumescence large, pale covered by few hairs. Labium 0.90 long, 1.70 wide, with three cuspules. Each endite with 63 cuspules. Sternum 4.40 long, 3.60 wide. Posterior sternal sigilla median and submarginal. Palp, measurements: femur 4.56/ patella 1.60/ tibia 2.32/ cymbium 2.00/ total 10.48; spination: femur d0-0-5, patella 0 , tibia d0-1-2, r0-0-2, v1-3-1, p3-4-1, cymbium 0. Legs, measurements: I: femur $8.40 /$ patella 4.49 / tibia 7.20 / metatarsus $7.78 /$ tarsus 5.12/ total 32.99; II: 8.56/4.32/6.40/7.77/5.12/32.17; III: 7.36/3.76/5.08/8.24/4.04/29.48; IV: 9.65/4.64/7.88/10.45/5.76/ 38.38; spination: I: femur d1-2-5, patella d2, tibia r1-1-0, v4-4-0 (3ap), p1-1-1, megaspine absent, metatarsus d1-2-0, r0-1-0, v2-10 (2ap); II: femur d3-4-3, patella d2, tibia d1-1-1, v2-3-0 (3ap), p01-0, metatarsus d1-2-1, r0-1-0, v2-2-0 (3ap); III: femur d4-3-3, patella d3, tibia d3-0-3, v2-2-0 (3ap), metatarsus d4-4-4, v2-2-0 (4ap); IV: femur d1-5-3, patella 0, tibia d3-3-2, v2-2-0 (3ap), metatarsus d4-5-4, v3-1-3 (3ap), p0-1-1. Scopulae of tarsi II, III, IV divided by a row of thin setae. Third claw present on tarsus IV. Superior tarsal claws large with a double row of six to eight teeth each. Four spinnerets. Apical segment of the posterior lateral spinnerets short, triangular. Palp with elongate tibia. Embolus distally twisted at a $30^{\circ}$ angle and with an inconspicuous opening (Figs 4-6).

Female. Unknown. 


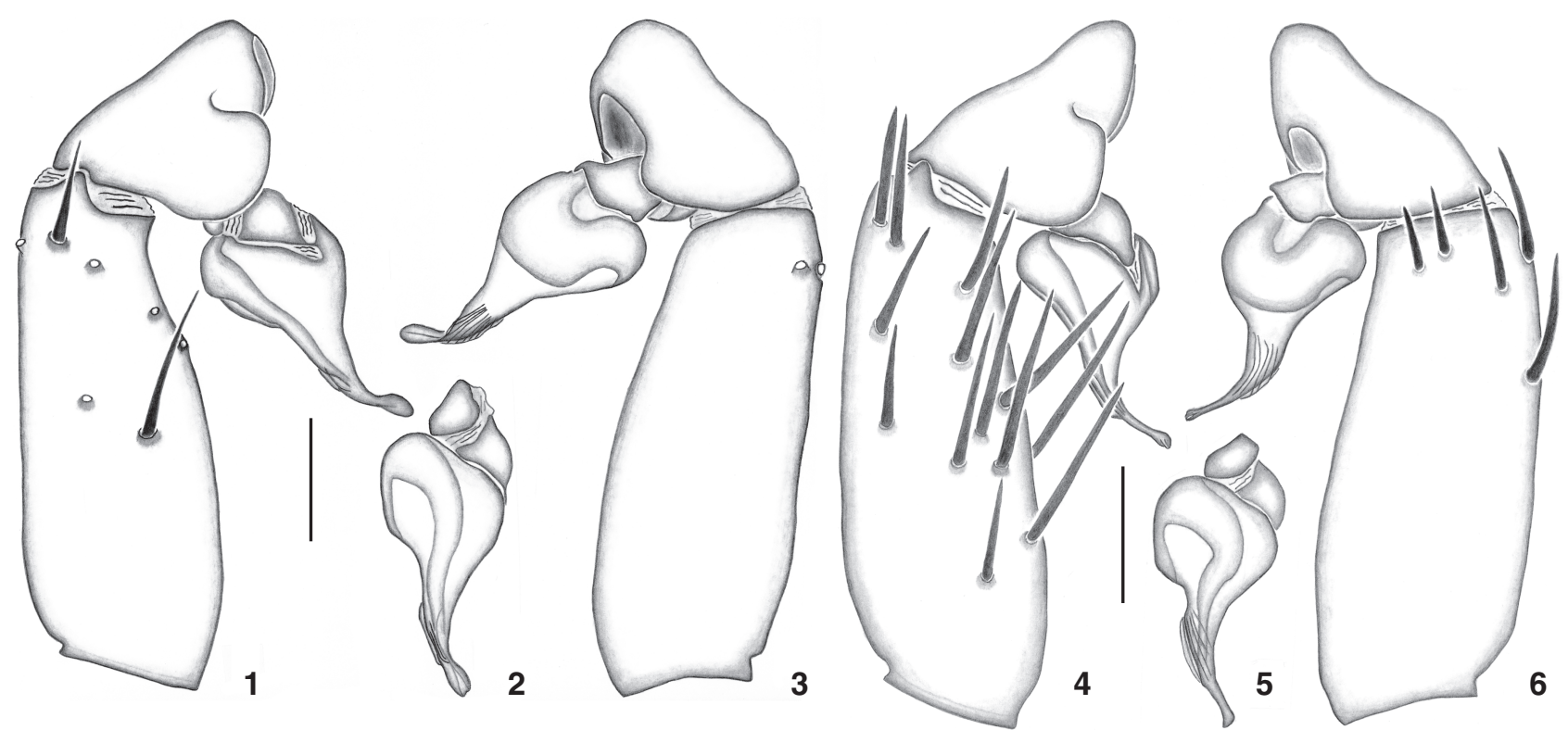

Figures 1-6. (1-3) Psalistopoides fulvimanus, male palpal bulb: (1) prolateral view; (2) dorsal view; (3) retrolateral view. (4-6) Psalistopoides emanueli sp. nov., male palpal bulb: (4) prolateral view; (5) dorsal view; (6) retrolateral view. Scale bars $=1 \mathrm{~mm}$.

Variation. Total length 18.30-23.65. Labium with 3-5 cuspules.

Distribution. Only known from the type-locality.

\section{ACKNOWLEDGMENTS}

To Antonio D. Brescovit, Cristina A. Rheims, Gustavo R.S. Ruiz (IBSP), Erica H. Buckup, Ricardo Ott (Fundação Zoobotânica, Porto Alegre). The study was supported by "Fundação de Amparo à Pesquisa do Estado de São Paulo" (Fapesp n 99/5446-8) and Coordenação de Aperfeiçoamento de Pessoal de Nível Superior (CAPES), and was developed in the Programa de Pós-Graduação em Biologia Animal da Universidade Federal Rural do Rio de Janeiro.

\section{REFERENCES}

BONNET, P. 1958. Bibliographia araneorum. Toulouse, 2 (4): 3027-4230.

Bücherl, W.; A Timotheo-DA-Costa \& S. LucAs. 1971. Revisão de alguns tipos de aranhas caranguejeiras (Orthognatha) estabelecidos por Cândido de Mello Leitão e depositados no Museu Nacional do Rio. Memórias do Instituto Butantan, São Paulo, 35: 117-138.

InDicatTI, R.P. \& S.M. LuCAS. 2005. Description of a new genus of Nemesiidae (Araneae, Mygalomorphae) from the Brazilian Cerrado. Zootaxa, Frankfurt, 188: 11-16.

LuCAS, S. \& W. BüChERL. 1973. Revision von Typenmaterial der Vogelspinnensammlung des Institutes Butantan. Zoologischer Anzeiger, Leipzig, 190: 237-250.
Goloboff, P.A. 1995. A revision of the South American spiders of the family Nemesiidae (Araneae, Mygalomorphae). Part I: species from Peru, Chile, Argentina, and Uruguay. Bulletin of the American Museum of Natural History, New York, 224: 1-189.

Mello-Leitão, C.F. DE. 1934. Três aranhas novas nas colleções do Instituto Butantan. Memórias do Instituto Butantan, São Paulo, 8: 401-407.

Petrunkevitch, A. 1939. Catalogue of American spiders. Part one. Transactions of the Connecticut Academy of Arts and Sciences, Connecticut, 33: 133-338.

Platnick, N.I. 2006. The world spider catalog, version 6.5. American Museum of Natural History, New York, available on line at http://research.amnh.org/entomology/spiders/ catalog/index.html [accessed in 19/I/2006].

RAVEN, R.J. 1985. The spider infraorder Mygalomorphae (Araneae): cladistics and systematics. Bulletin of the American Museum of Natural History, New York, 182: 1-180.

Roewer, C.F. 1942. Katalog der Araneae von 1758 bis 1940. Bremen, Natura, vol. 1, VIII+1040p.

Simon, E. 1892. Etudes arachnologiques. 24e Mémoire. XXXIX. Descriptions d'espèces et de genres nouveaux de la famille des Aviculariidae (suite). Analles de la Société Entomologique de France, Paris, 61: 271-284.

Vellard, J. 1924. Etudes de zoologie. Archivos do Instituto Vital Brasil, Niterói, 2: 1-32, 121-170.

Received in 17.VIII.2005; accepted in 16.V.2006.

Revista Brasileira de Zoologia 23 (2): 547-549, junho 2006 